\title{
Processing and secretion by Escherichia coli of a recombinant form of the immunogenic protein MPB70 of Mycobacterium bovis
}

\author{
R. Glyn Hewinson ${ }^{1 *}$ and William P. RusSell ${ }^{2}$ \\ Molecular Genetics Unit ${ }^{1}$ and Applied and Molecular Immunology Unit ${ }^{2}$, Central Veterinary Laboratory, New Haw, \\ Weybridge, Surrey KT15 3NB, UK
}

(Received 16 November 1992; revised 25 January 1993; accepted 1 February 1993)

\begin{abstract}
The gene encoding an immunodominant secreted antigen, MPB70, of Mycobacterium bovis was cloned into the plasmid vector pBluescript II $\mathrm{KS}^{+}$along with its native ribosome-binding site. In this construct translation of the protein in Escherichia coli was from the native AUG initiation codon and was directed by the mycobacterial ribosome-binding site. Two different molecular mass forms $(26 \mathrm{kDa}$ and $22 \mathrm{kDa})$ of MPB70 were observed in whole-cell pellets of recombinant $E$. coli. The difference in size indicates cleavage of the signal peptide of MPB70 by an endopeptidase of $E$. coli. MPB70 was secreted into the periplasm of recombinant $E$. coli, where the $22 \mathrm{kDa}$ form of the protein was predominant. The culture filtrate contained only the $22 \mathrm{kDa}$ form of the protein, which was soluble. The passage of MPB70 from the periplasm into the growth medium was found to be due, at least in part, to non-specific leakage of periplasmic proteins across the outer membrane associated with the expression of recombinant MPB70.
\end{abstract}

\section{Introduction}

Improvement of immunodiagnostic screening for $\mathrm{Myco-}$ bacterium bovis infection relies on the identification and purification of antigens exhibiting a high degree of specificity (Daniel \& Janicki, 1978; Auer, 1987; Fifis et al., 1992). In order to identify such antigens for diagnosis in cattle, Fifis et al. (1992) purified a number of proteins from $M$. bovis and tested these antigens with panels of sera from $M$. bovis-infected cattle, $M$. bovis culturenegative cattle, and cattle infected with other mycobacteria. Their study identified a number of promising candidate antigens, of which the protein MPB70 gave greatest specificity for $M$. bovis infection.

MPB70 is an immunodominant antigen of $M$. bovis (Fifis et al., 1989) containing $M$. bovis species-specific epitopes (Wood et al., 1988). The protein is an active component of bovine PPD (Harboe et al., 1990) and is able to elicit a delayed-type hypersensitivity (DTH) response (Nagai et al., 1981; Miura et al., 1983; Harboe et al., 1986; Hasløv et al., 1987), and to stimulate $\mathrm{T}$ lymphocyte proliferation (Fifis et al., 1989; Griffin et al., 1991) and antibody production (Fifis et al., 1992; Wood et al., 1992) in M. bovis-infected animals. The protein is a major component of $M$. bovis culture filtrate (Nagai et al., 1981; Harboe et al., 1986; Abou-Zeid et al., 1987;

\footnotetext{
*Author for correspondence.
}

Fifis et al., 1991) and is secreted from the cell following cleavage of a 30 -amino-acid signal peptide which directs translocation of the hydrophobic molecule across the cytoplasmic membrane (Terasaka et al., 1989). MPB70 has been cloned and sequenced (Terasaka et al., 1989; Radford et al., 1990).

The use of isolated M. bovis antigens, such as MPB70, in immunodiagnostic assays is hindered by difficulties in growing the organism and purifying the antigens. Recombinant proteins may provide a realistic alternative. Previous reports have indicated that bulk purification of mycobacterial recombinant proteins in Escherichia coli may be achieved by fusion of the protein of interest to a second protein for which column purification procedures are available. However, this often results in the accumulation of the fusion protein as an insoluble protein mass within the bacterial cell (Vordermeier et al., 1991; Ashbridge et al., 1992), making purification difficult.

This report describes the production of a plasmid construct which generates a form of MPB70 with retained antigenicity, that is secreted across the cytoplasmic membrane of $E$. coli. The results indicate that the leader peptide of the recombinant mycobacterial protein is cleaved by an endopeptidase of $E$. coli, resulting in the accumulation of a soluble, mature form of the protein in the periplasm and growth medium, thus facilitating purification. 


\section{Methods}

Bacterial strains and vectors. Escherichia coli strain $\mathrm{DH} 5 \alpha\left(\mathrm{F}^{-}\right.$ $\phi 80$ lacZAM15 $\Delta($ lacZYA-argF $) \mathrm{U} 169$ recAl endAI hsdRI7 $\left(\mathrm{r}_{\mathrm{k}}^{-} \mathrm{m}_{\mathrm{k}}^{+}\right)$ supE44 $\lambda^{-}$thi-1 gyrA relAI) was used as host for plasmid vectors pBluescript II $\mathrm{KS}^{+}$(Stratagene), pUC18 and pUC19 (Gibco-BRL). The $M$. bovis DNA used in this study was extracted from strain AN5 (Central Veterinary Laboratory, Weybridge, UK).

Immunological reagents. $M$. bovis sonicated extract was prepared by the method of Morris et al. (1985). Rabbits were immunized subcutaneously at multiple sites with $M$. bovis sonicated extract $(100 \mu \mathrm{g})$ in Freund's incomplete adjuvant. The rabbits were boosted twice at $14 \mathrm{~d}$ intervals. Murine anti-MPB70 monoclonal antibody, SB10 (Wood et al., 1988), was purchased from Agen Biomedical (Queensland, Australia). Rabbit antibody directed against $\beta$-lactamase of E. coli was purchased from CP Laboratories (Hertfordshire, UK).

Polymerase chain reaction (PCR). DNA was extracted from M. bovis strain AN5 by the method of Whipple et al. (1987). PCR was performed in $50 \mu \mathrm{l}$ reaction mixtures containing $50 \mathrm{~mm}-\mathrm{KCl}, 10 \mathrm{~mm}-$ Tris/ $\mathrm{HCl}(\mathrm{pH} 8 \cdot 8), 0.01 \%$ (w/v) gelatin, $3 \mathrm{mM}-\mathrm{MgCl}_{2}, 200 \mu \mathrm{M}$ of each dinucleotide triphosphate (dNTP), $2.5 \mathrm{U}$ of thermostable Taq DNA polymerase (Perkin-Elmer Cetus) and $20 \mathrm{pmol}$ of each oligonucleotide primer. The DNA sequence of the primers was as follows: 5'AAAGAATTCGGACGGCTCCGAAGAAATC- $3^{\prime}$ and $5^{\prime}$ CCCGGATCCTTACGCCGGAGGCATTAGCAC- $3^{\prime}$. The reaction mixture was overlaid with $50 \mu \mathrm{l}$ mineral oil and DNA samples (10 ng) were pipetted through the oil into the mixture. The parameters for amplification were: denaturation at $94^{\circ} \mathrm{C}$ for $3 \mathrm{~min}$ for one cycle, followed by 30 cycles at $94{ }^{\circ} \mathrm{C}$ for $1.5 \mathrm{~min}, 56^{\circ} \mathrm{C}$ for $1.5 \mathrm{~min}$ and $72{ }^{\circ} \mathrm{C}$ for $2 \mathrm{~min}$. A final extension at $72{ }^{\circ} \mathrm{C}$ for $10 \mathrm{~min}$ was also included. A reagent blank (negative control) was as described above but without the addition of DNA sample.

Sequence analysis. DNA sequencing of double-stranded template was performed using the primer-extension dideoxy chain-termination method (Sanger et al., 1977) as recommended by the manufacturer (Sequenase, United States Biochemicals).

Other genetic procedures. Restriction endonucleases and other enzymes were used according to the manufacturers' instructions. Other genetic manipulations were as described by Sambrook et al. (1989).

Osmotic shock procedure. The method used to obtain periplasmic and cytoplasmic cell fractions was a modification of that described by Koshland \& Botstein (1980). A $10 \mathrm{ml}$ overnight culture of bacterial cells was grown in Luria-Bertani broth, with $0.1 \%(\mathrm{w} / \mathrm{v})$ glucose added (LBG; Sambrook et al., 1989), in the presence of $100 \mu \mathrm{g}$ ampicillin $\mathrm{ml}^{-1}$. The culture was harvested by centrifugation at $5000 \mathrm{~g}, 15 \mathrm{~min}$, $20^{\circ} \mathrm{C}$. The supernatant was discarded and the cells washed twice in $40 \mathrm{ml} \mathrm{LBG}$ broth. The final pellet was resuspended in $10 \mathrm{ml} \mathrm{LBG}$ broth and $1 \mathrm{ml}$ was inoculated into $100 \mathrm{ml} \mathrm{LBG}$ broth with $50 \mu \mathrm{g}$ ampicillin $\mathrm{ml}^{-1}$ in a $250 \mathrm{ml}$ conical flask. The cells were incubated at $37^{\circ} \mathrm{C}$, 200 r.p.m. for $2-4 \mathrm{~h}$ until an $\mathrm{OD}_{550}$ of $0.5-0.7$ was obtained (i.e. exponential-phase growth).

The $\mathrm{OD}_{550}$ of the cells was standardized to 0.5 by dilution in LBG broth. The cell suspension $(50 \mathrm{ml})$ was harvested by centrifugation; the supernatant was removed and filtered twice through $0 \cdot 2 \mu \mathrm{m}$ filters. The filtrate was concentrated to 0.09 volumes (i.e. 11 -fold concentration) by ultrafiltration (Centricon, Amicon) and saved as the culture filtrate fraction. The cell pellet was resuspended in $4.5 \mathrm{ml}$ ice-cold $20 \%(\mathrm{w} / \mathrm{v})$ sucrose, $10 \mathrm{~mm}$-Tris $/ \mathrm{HCl}$ (pH 7.5). EDTA solution $(0.5 \mathrm{M}, \mathrm{pH} 8$, $150 \mu \mathrm{l}$ ) was added and incubation was continued on ice for $10 \mathrm{~min}$. All subsequent steps were carried out at $4{ }^{\circ} \mathrm{C}$. A sample $(1.5 \mathrm{ml})$ was removed for use as the untreated control. The remaining cell suspension was dispensed in $1.5 \mathrm{ml}$ volumes into Eppendorf tubes and centrifuged for $5 \mathrm{~min}$ at $13000 \mathrm{~g}, 4^{\circ} \mathrm{C}$. The supernatant fluid was removed quickly and the pellet rapidly resuspended by vigorous agitation in $1 \mathrm{ml}$ icecold distilled water. The mixture was incubated for $10 \mathrm{~min}$ on ice and then centrifuged for $10 \mathrm{~min}$ at $13000 \mathrm{~g}, 4^{\circ} \mathrm{C}$. The supernatant fluid was recovered (periplasmic fraction). Residual fluid was removed carefully from the cells and the remaining cell pellet was resuspended in $1 \mathrm{ml}$ distilled water (the cytoplasmic fraction). All cellular fractions were stored at $-20^{\circ} \mathrm{C}$ prior to use.

Determination of $\beta$-lactamase activities. The hydrolysis of the chromogenic cephalosporin nitrocefin (O'Callaghan et al., 1972) by $\beta$ lactamase at $37^{\circ} \mathrm{C}$ was monitored at $550 \mathrm{~nm}$ (Angus et al., 1982). The molar absorption coefficient for nitrocefin was $10.71 \mathrm{mmol}^{-1} \mathrm{~cm}^{-1}$. The reaction mixture (final volume $1 \mathrm{ml}$ ) contained $5 \mathrm{mM}-\mathrm{MgCl}_{2} / 25 \mathrm{mM}$ MOPS ( $\mathrm{pH} 7 \cdot 4$ ) and 13-126 $\mu \mathrm{M}$-nitrocefin. The reaction was started by the addition of $10 \mu \mathrm{l}$ of osmotic shock fraction. Initial rates of nitrocefin hydrolysis by the $\beta$-lactamase present in each osmotic shock fraction were determined by the chord-drawing method of Waley (1981). Values for $K_{\mathrm{m}}$ and $V_{\max }$ of the $\beta$-lactamase in each osmotic shock preparation were determined using linear regression analysis of Lineweaver-Burk plots. From these, a mean value of the $K_{\mathrm{m}}$ for nitrocefin hydrolysis by the $\beta$-lactamase encoded by pBluescript II $\mathrm{KS}^{+}$ was obtained. To enable direct comparison of $V_{\max }$ for all experiments, the mean of the $K_{\mathrm{m}}$ values was used to calculate $V_{\max }$ from initial rates of nitrocefin hydrolysis using the Michaelis-Menten equation.

$S D S$ - $P A G E$. Protein samples $(50 \mu \mathrm{l})$ were solubilized by heating at $100^{\circ} \mathrm{C}$ for $3 \mathrm{~min}$ in $50 \mu \mathrm{l}$ sample loading buffer $[75 \mathrm{mM}$-Tris $/ \mathrm{HCl}$, $\mathrm{pH} 6.8,5 \%(\mathrm{v} / \mathrm{v})$ 2-mercaptoethanol, $2 \%(\mathrm{w} / \mathrm{v})$ sodium dodecyl sulphate, $10 \%(\mathrm{v} / \mathrm{v})$ glycerol, $0.002 \%(\mathrm{w} / \mathrm{v})$ bromophenol blue]. Fractions were then separated on a $12.5 \%$ (w/v) SDS-polyacrylamide gel using a discontinuous $\mathrm{Tris} / \mathrm{HCl}$ buffer system as described by Laemmli (1970). Rainbow protein markers (Amersham) were run as molecular mass standards.

Immunoblotting. Proteins were transferred to nitrocellulose by electroblotting as described by Matsudaira (1987). Membranes were blocked with $3 \%(\mathrm{w} / \mathrm{v})$ bovine serum albumin (BSA) in phosphatebuffered saline (PBS) for $30 \mathrm{~min}$, washed in PBS with $0.05 \%(\mathrm{w} / \mathrm{v})$ Tween 20 (PBST) and incubated for $1 \mathrm{~h}$ with rabbit antiserum directed against sonicated $M$. bovis (diluted 1 in 500 in PBST), or with rabbit antiserum directed against $\beta$-lactamase (diluted 1 in 500 in PBST). Membranes were washed and incubated for $30 \mathrm{~min}$ at $20^{\circ} \mathrm{C}$ with alkaline-phosphatase-conjugated anti-rabbit immunoglobulin (Sigma; diluted 1 in 8000 in PBST). After washing, bound alkaline phosphatase was detected using Nitro Blue Tetrazolium as described by Blake $e t$ al. (1984).

\section{Results}

Cloning of the gene encoding MPB70 and its expression in E. coli

PCR was used to amplify the gene encoding MPB70 from chromosomal DNA extracted from $M$. bovis AN5. The oligonucleotide primers used in this reaction were designed to give a product of $678 \mathrm{bp}$ encompassing $660 \mathrm{bp}$ of mycobacterial DNA encoding the MPB70 structural gene with an additional $78 \mathrm{bp}$ upstream of the AUG initiation codon and restriction endonuclease sites at each end to allow cloning into the plasmid vector. The upstream region of DNA included a putative ribosomebinding site at positions -13 to -9 from the initiation codon (Terasaka et al., 1989; Radford et al., 1990). Thus 


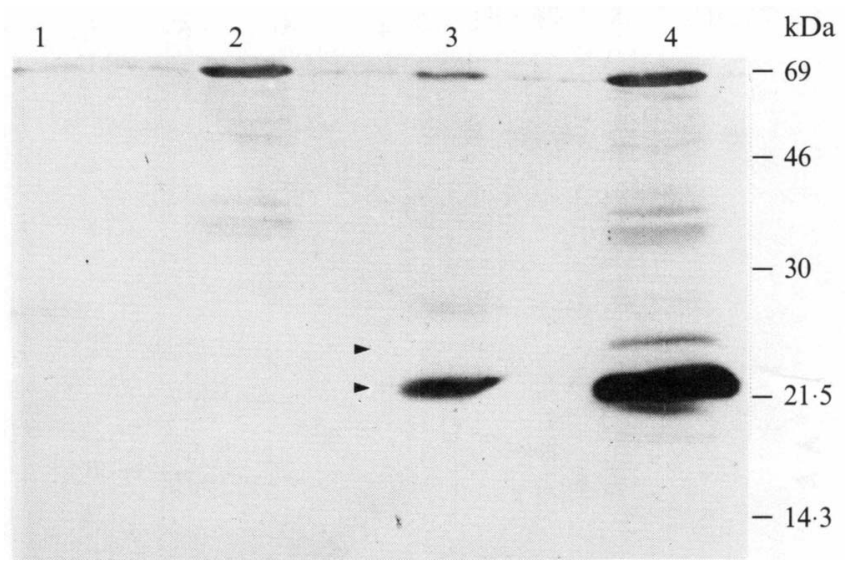

Fig. 1. Western blots of recombinant $E$. coli clones incubated with polyclonal antisera directed against sonicated $M$. bovis. pBluescript II $\mathrm{KS}^{+}$is the original plasmid vector. Plasmid pVW500 was constructed by cloning the gene encoding MPB70 into pBluescript $\mathrm{II} \mathrm{KS}^{+}$as described in Results. Lanes: 1, E. coli DH5 $\alpha\left(\mathrm{pBluescript}\right.$ II $\left.\mathrm{KS}^{+}\right)$ culture filtrate; 2, E. coli $\mathrm{DH} 5 \alpha\left(\mathrm{pBluescript} \mathrm{II} \mathrm{KS}^{+}\right)$cell pellet; $3, E$. coli DH5 $\alpha(\mathrm{pVW} 500)$ culture filtrate; $4, E$. coli $\mathrm{DH} 5 \alpha(\mathrm{pVW} 500)$ cell pellet. Arrowheads indicate the positions of the two forms of MPB70.

it was envisaged that by cloning the PCR product into the vector pBluescript II $\mathrm{KS}^{+}$transcription of the gene encoding MPB70 would occur from the lac $Z$ promoter of the vector and that translation of MPB70 would occur from ribosomes binding to the cloned ribosome-binding site. A 678 bp product was obtained from the PCR and was ligated into pBluescript II $\mathrm{KS}^{+}$using the $E c o$ RI and BamHI restriction endonuclease sites encoded by the oligonucleotide primers. The recombinant plasmid was transformed into $E$. coli $\mathrm{DH} 5 \alpha$. The identity of the mycobacterial insert in $E$. coli transformed with the recombinant plasmid was confirmed by DNA sequence analysis. The recombinant plasmid was designated pVW500.

Expression of MPB70 was detected by Western blotting using polyclonal rabbit antisera directed against sonicated M. bovis. Two forms of MPB 70 were observed in the cell pellet (Fig. 1, lane 4). These polypeptides were not detected in the cell pellet of control recombinant $E$. coli containing plasmid without the mycobacterial DNA insert (Fig. 1, lane 2). One form of MPB70 gave an apparent molecular mass of $26 \mathrm{kDa}$, the other, predominant form, gave an apparent molecular mass of $22 \mathrm{kDa}$ as estimated by denaturing PAGE. The expression of MPB70 was confirmed by Western blot analysis of the recombinant proteins using SB10, a monoclonal antibody specific for MPB70 (Wood et al., 1988). SB10 bound both forms of recombinant MPB70, although its affinity for the polypeptides was not as high as that of the polyclonal antisera (data not shown).

In order to determine whether transcription of MPB70 was from a promoter present in the $78 \mathrm{bp}$ of $M$. bovis
DNA upstream of the MPB70 initiation codon or from the $l a c Z$ promoter of the plasmid vector, the entire DNA fragment was excised from pVW500 using EcoRI and BamHI endonuclease digestion and ligated into the plasmid vectors $\mathrm{pUC1} 18$ and $\mathrm{pUC19}$. This procedure introduced the DNA fragment into $\mathrm{pUC}$ in both orientations relative to the $l a c Z$ promoter. Western blot analysis using the rabbit antisera raised against sonicated $M$. bovis showed that MPB70 was only expressed by recombinant $E$. coli containing the pUC18 construct, i.e. in the same orientation as pVW500, suggesting that expression was under control of the lac $Z$ promoter.

\section{Secretion of MPB70 by E. coli}

Western blotting of concentrated culture filtrate using rabbit antisera raised against sonicated $M$. bovis detected the presence of only the $22 \mathrm{kDa}$ form of recombinant MPB70 in the culture medium (Fig. 1, lane 3). This suggested that MPB70 was expressed and secreted by $E$. coli via a mechanism involving cleavage of the secretory signal peptide. In order to confirm this, osmotic shock was used to obtain cytoplasmic and periplasmic fractions of the recombinant cells. These fractions, and the culture filtrates from recombinant $E$. coli, with and without the MPB70 DNA insert, were Western blotted with antisera directed against sonicated $M$. bovis (Fig. 2a). The majority of the $26 \mathrm{kDa}$ form of MPB70 was restricted to the cytoplasmic fraction of recombinant $E$. coli (lane 3), whereas the $22 \mathrm{kDa}$ form was detected in the culture filtrate, the cytoplasm and the periplasm (lanes 1-3).

The cellular fractions were also analysed for the presence of $\beta$-lactamase (a periplasmic protein of $29 \mathrm{kDa}$ that is synthesized as a preprotein with a typical signal peptide of 23 amino acids: Sutcliffe, 1978; Koshland \& Botstein, 1980), which was encoded by the plasmid vector. $\beta$-Lactamase was detected by Western blotting using specific rabbit antisera (Fig. $2 b$ ). A similar pattern of $\beta$-lactamase secretion to that of MPB70 was observed. Two forms of $\beta$-lactamase (of approximately $31.5 \mathrm{kDa}$ and $29 \mathrm{kDa}$ ) were detected in the cytoplasm and periplasm (lanes 2, 3, 5 and 6), although the lower molecular mass form was predominant in the periplasm (lanes 2 and 5). The lower molecular mass form was also observed in the culture filtrate (lanes 1 and 4), suggesting some leakage across the outer membrane.

\section{Measurement of $\beta$-lactamase leakage across the outer membrane of recombinant $E$. coli}

In order to establish whether the presence of MPB70 in the culture filtrate was due to active secretion via a specific pathway, or to a general increase in the leakage of proteins through the outer membrane, the $\beta$-lactamase 

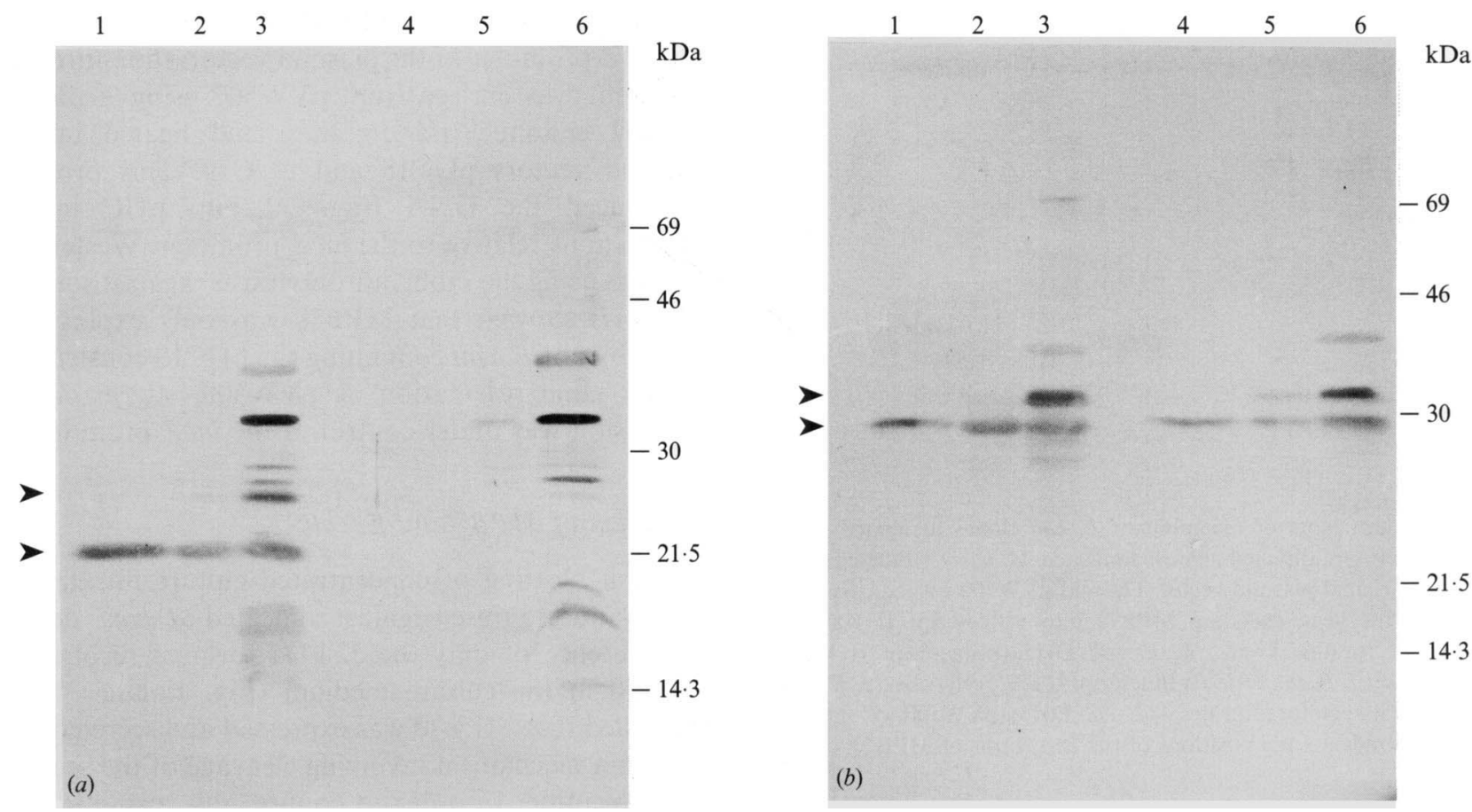

Fig. 2. (a) Western blots of cellular fractions of recombinant $E$. coli clones incubated with polyclonal sera raised against sonicated $M$. bovis. Plasmid pBluescript II KS ${ }^{+}$is the original plasmid vector. Plasmid pVW500 was constructed by cloning the gene encoding MPB70 into pBluescript II KS ${ }^{+}$as described in Results. Lanes: 1, E. coli DH5 $\alpha(\mathrm{pVW} 500)$ culture filtrate; 2 , E. coli DH5 $\alpha$ (pVW500) periplasmic fraction; 3, E. coli DH5 $\alpha(\mathrm{pVW} 500)$ cytoplasmic fraction; 4, E. coli DH5 $\alpha\left(\mathrm{pBluescript} \mathrm{II} \mathrm{KS}^{+}\right)$culture filtrate; 5 , E. coli DH5 $\alpha$ (pBluescript II $\mathrm{KS}^{+}$) periplasmic fraction; $6, E$. coli $\mathrm{DH} 5 \alpha\left(\mathrm{pBluescript}\right.$ II $\left.\mathrm{KS}^{+}\right)$cytoplasmic fraction. Arrowheads indicate the positions of the two forms of MPB70. (b) Western blots of cellular fractions of recombinant $E$. coli clones incubated with polyclonal sera raised against $\beta$-lactamase. Lanes 1 to 6 as for $(a)$. Arrowheads indicate the positions of the two forms of $\beta$-lactamase.

Table 1. $\beta$-Lactamase activities of cellular fractions of recombinant E. coli

Bacteria were grown to early exponential phase growth in LBG broth. The cells were harvested and the cellular fractions obtained by osmotic shock treatment. Hydrolysis of nitrocefin was monitored spectrophotometrically $\left(550 \mathrm{~nm}\right.$ ) at $37^{\circ} \mathrm{C}$ in $5 \mathrm{~mm}-\mathrm{MgCl}_{2} / 25 \mathrm{mM}-\mathrm{MOPS}(\mathrm{pH} 7 \cdot 4)$. Initial rates of hydrolysis were determined by the chord-drawing method of Waley (1981) and were used to calculate $K_{\mathrm{m}}$ and $V_{\max }$ using Lineweaver-Burk plots. A mean $K_{\mathrm{m}}$ value of $35 \cdot 7 \pm 8 \cdot 4 \mu \mathrm{M}(n=10)$ was obtained. This value was used to calculate $V_{\max }\left[\mathrm{nmol} \mathrm{min}{ }^{-1}\right.$ (mg dry mass $)^{-1}$ ] from each initial rate of hydrolysis using the Michaelis-Menten equation. The SEM was calculated from the values obtained using either $27(*)$ or $12(\dagger)$ initial rates of nitrocefin hydrolysis in the concentration range $10-120 \mu \mathrm{M}$-nitrocefin from three separate experiments.

\begin{tabular}{lcccc}
\hline \hline $\begin{array}{l}\text { Plasmid in } \\
\text { E. coli DH5 } \alpha\end{array}$ & $\begin{array}{c}V_{\max } \\
\text { culture filtrate }\end{array}$ & $\begin{array}{c}V_{\max } \\
\text { periplasmic }\end{array}$ & $\begin{array}{c}V_{\max } \\
\text { cytoplasmic }\end{array}$ & $\begin{array}{c}V_{\max } \text { culture filtrate/ } \\
V_{\max } \text { periplasmic }\end{array}$ \\
\hline $\begin{array}{l}\text { pBluescript II } \mathrm{KS}^{+} \\
\text {pVW500 }\end{array}$ & $1017\left( \pm 424^{*}\right)$ & $3111\left( \pm 184^{*}\right)$ & $178( \pm 47 \dagger)$ & 0.33 \\
\hline
\end{tabular}

activity was measured in each of the cellular fractions. The results of three experiments comparing the $\beta$ lactamase activities in the cellular fractions of recombinant $E$. coli expressing MPB70 and E. coli containing plasmid without the MPB70 insert are shown in Table 1. The $\beta$-lactamase activities in the culture filtrate were consistently higher for $E$. coli expressing

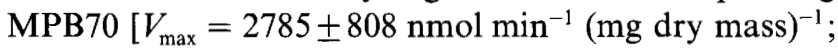
mean \pm SEM, $n=27$ ] than the activities observed for recombinant $E$. coli that did not express $\operatorname{MPB} 70\left[V_{\max }=\right.$
$1017 \pm 424 \mathrm{nmol} \mathrm{min}^{-1}$ (mg dry mass) $\left.{ }^{-1} ; n=27\right]$. The ratio $V_{\max }$ culture filtrate $/ V_{\max }$ periplasm was 1.68 for $E$. coli expressing MPB70 whereas for cells not expressing MPB70 it was only $0 \cdot 33$.

\section{Discussion}

The intention of this study was to produce recombinant antigens for the development of sensitive and specific blood-based immunodiagnostic tests of $M$. bovis 
infections in domestic and wild animals. Antigen production in $E$. coli rather than in $M$. bovis reduces the problems associated with the slow generation time of $M$. bovis, the infectivity of the pathogen and the more complex biochemical composition of mycobacteria. The immunogenic protein MPB70 is a suitable candidate antigen for diagnosis since it has been shown to be the most specific antigen for serodiagnosis of $M$. bovis infection in cattle (Fifis et al., 1992). Fortuitously, the recombinant MPB70 produced in this study was found to be secreted across the cytoplasmic membrane of $E$. coli and to accumulate in the periplasm and culture medium of the organism.

Since the plasmid construct encoding MPB70 (pVW500) also contained 81 bp of mycobacterial DNA upstream from the initiation codon, it was possible that transcription of MPB70 was initiated from a mycobacterial promoter present in this DNA fragment. However, as expression was only observed in one orientation of the mycobacterial DNA insert relative to the lac $Z$ promoter, we conclude that it is most likely that transcription is directed from the lac $Z$ promoter of the plasmid vector. This result is consistent with the sequencing data of Terasaka et al. (1989), which identified putative promoter sequences at positions -148 to -143 and -124 to -119 upstream of the MPB70 initiation codon (i.e. outside the DNA region contained in pVW500). Moreover, insertion of the PCR product into the lac $Z$ gene of pBluescript II $\mathrm{KS}^{+}$and pUC18 introduced a stop codon in the $l a c Z$ gene at positions -8 to -6 from the initiation codon of the MPB70 structural gene, thus creating a two-cistron expression system (Schoner et al., 1984). It therefore seems likely that expression of MPB70 was achieved by translational coupling (Schoner et al., 1984). In this system it is envisaged that transcription is initiated from the $\operatorname{lac} Z$ promoter, the $E$. coli ribosomes bind the putative ribosome-binding site (Terasaka et al., 1989; Radford et al., 1990) encoded by the $M$. bovis DNA insert and MPB70 is translated from its native AUG initiation codon. In some cases this type of two-cistron construction has been shown to improve the efficiency of translation of heterologous genes in $E$. coli (Schoner et al., 1984).

Two forms $(26 \mathrm{kDa}$ and $22 \mathrm{kDa})$ of the recombinant MPB70 were produced by $E$. coli containing the plasmid construct pVW500. Analysis of the protein sequence of MPB70 reveals the presence of a 30-amino-acid secretory signal sequence at the amino-terminus of the protein (Terasaka et al., 1989; Radford et al., 1990). This is cleaved from the mature protein during secretion by $M$. bovis (Radford et al., 1990). The signal peptide of MPB70 conforms to the physico-chemical properties observed for other bacterial signal peptides (Von Heijne, 1988) in that the peptide has a positively charged amino-terminal region, a central hydrophobic region and a more polar carboxy-terminal with an Ala-X-Ala endopeptidase recognition site. The difference in molecular mass of the two forms of MPB70 can therefore be explained by cleavage of the 30-amino-acid secretory signal peptide (Terasaka et al., 1989; Radford et al., 1990) from the $26 \mathrm{kDa}$ form of MPB70 by an endopeptidase of E. coli. The molecular mass of mature MPB70 predicted from the amino acid sequence is $16 \cdot 3 \mathrm{kDa}$ (Terasaka et al., 1989; Radford et al., 1990) rather than the observed $22 \mathrm{kDa}$. However, mature native MPB70 from M. bovis also displays aberrant mobility in denaturing PAGE, giving an apparent molecular mass of 18-23 kDa (Miura et al., 1983; Nagai et al., 1986; Abou-Zeid et al., 1987; Hasløv et al., 1987; Fifis et al., 1989). Therefore, when the signal peptide is removed, both native and recombinant MPB70 display similar aberrant mobilities. Preliminary unpublished data suggest that the $\mathrm{pI}$ of the recombinant form of MPB70 (4.8) is similar to the value of 4.5-5.0 reported for native MPB70 (Nagai et al., 1986; Fifis et al., 1989).

Secretion of recombinant MPB70 into the periplasm of $E$. coli was observed. To our knowledge this is the first report of the secretion of a mycobacterial protein by a Gram-negative bacterium. Moreover, the $22 \mathrm{kDa}$ form of MPB70 was detected in both the periplasm and culture filtrate of recombinant $E$. coli in the exponential phase of growth. Since the signal peptide of MPB70 was removed following translocation across the cytoplasmic membrane, it seemed likely that the appearance of MPB70 in the culture medium was either due to nonspecific leakage across the outer membrane or to a specific, signal-peptide-independent process. Recent studies indicate that several pathways exist for the secretion of proteins across the outer membrane (Pugsley, 1989). However, our results show that the expression of MPB70 in E. coli gives rise to an increase in leakage of the normally periplasmic $\beta$-lactamase across the outer membrane into the culture medium. Therefore the accumulation of recombinant MPB70 in the culture medium of $E$. coli is due, at least in part, to non-specific leakage of periplasmic proteins across the outer membrane. A likely explanation for this leakage is that hydrophobic interactions between the outer membrane and MPB70, which is a hydrophobic molecule (Terasaka et al., 1989), cause some disruption of the outer membrane. However, expression of MPB 70 did not affect the growth rate of the cells in culture (unpublished data).

This processing and secretion of the mycobacterial antigen MPB 70 by $E$. coli may be exploited for the purpose of antigen production. Production of MPB70 in this way has several advantages. Secretion precludes 
proteolysis of the protein by housekeeping cytoplasmic peptidases, which would normally remove abnormal proteins from the cytoplasm, and separates it from contaminating cytoplasmic proteins. Moreover, processing of the protein by $E$. coli results in the production of a mature, soluble form of MPB70 which resembles the native molecule, whereas recombinant proteins are often produced as chimeric fusion proteins which might alter the conformation of the protein.

The ability of $E$. coli to secrete MPB70 raises the possibility that $E$. coli and attenuated oral vaccine strains of salmonella might be able to secrete a range of mycobacterial antigens. This possibility is currently under investigation.

We are most grateful to Dr M. J. Woodward and Dr D. G. Newell for their invaluable help with the preparation of the manuscript. Nitrocefin was a kind gift from Glaxo Pharmaceuticals (Greenford, UK). This work was funded by the Ministry of Agriculture, Fisheries and Food.

\section{References}

Abou-Zeid, C., Harboe, M. \& Rook, G. A. W. (1987). Characterization of the secreted antigens of Mycobacterium bovis BCG : comparison of the 46-kilodalton dimeric protein with proteins MPB64 and MPB70. Infection and Immunity 55, 3213-3214.

Angus, B. L., Carey, A. M., Canon, D. A., Kropinski, A. M. B. \& HANCOCK, R. E. W. (1982). Outer membrane permeability in Pseudomonas aeruginosa: comparison of a wild-type with an antibiotic-supersusceptible mutant. Antimicrobial agents and Chemotherapy 21, 299-309.

Ashbridge, K. R., Backstrom, B. T., LiU, H.-X., Vikerfors, T., Englebretsen, D. R., Harding, D. R. K. \& Watson, J. D. (1992). Mapping of $T$ helper cell epitopes by using peptides spanning the 19$\mathrm{kDa}$ protein of Mycobacterium tuberculosis. Journal of Immunology 148, 2248-2255.

AUER, L. A. (1987). Assessment of an enzyme linked immunosorbent assay for the detection of cattle infected with Mycobacterium bovis. Australian Veterinary Journal 64, 172-176.

BLAKe, M. S., Johnston, K. H., RuSsel-Jones, G. J. \& Gatschlich, E. C. (1984). A rapid, sensitive method for detection of alkaline phosphatase conjugated anti-antibody on western blots. Analytical Biochemistry 136, 175-179.

DANIEL, T. M. \& JANICKI, B. W. (1978). Mycobacterial antigens: a review of their isolation, chemistry, and immunological properties. Microbiological Reviews 42, 84-113.

Fifis, T., Plackett, P., Corner, L. A. \& Wood, P. R. (1989). Purification of a major Mycobacterium bovis antigen for the diagnosis of bovine tuberculosis. Scandanavian Journal of Immunology 29, 91-101.

Fifis, T., Costopoulos, C., Radford, A. J., BaCic, A. \& Wood, P. R. (1991). Purification and characterization of major antigens from a Mycobacterium bovis culture filtrate. Infection and Immunity 59, 800-807.

Fifis, T., Costopoulos, C., Corner, L. A. \& Wood, P. R. (1992). Serological reactivity to Mycobacterium bovis protein antigens in cattle. Veterinary Microbiology 30, 343-354.

Griffin, J. F. T., NaGai, S. \& Buchan, G. S. (1991). Tuberculosis in domesticated red deer: comparison of purified protein derivative and the specific protein MPB70 for in vitro diagnosis. Research in Veterinary Science 50, 279-285.

Harboe, M., Nagai, S., Patarroyo, M. E., Torres, M. L., Ramirez, C. \& CRUZ, N. (1986). Properties of proteins MPB64, MPB70 and MPB80 of Mycobacterium bovis BCG. Infection and Immunity 52, 293-302.
Harboe, M., Wiker, H. G., Duncan, J. R., Garcia, M. M., Dukes, T. W., Brooks, B. W., Turcotte, C. \& NaGaI, S. (1990). Protein Gbased enzyme-linked immunosorbent assay for anti-MPB70 antibodies in bovine tuberculosis. Journal of Clinical Microbiology 28, 913-921.

Hasløv, K., Andersen, A. B. \& Bentzon, M. W. (1987). Biological activity in sensitized guinea pigs of MPB70, a protein specific for some strains of Mycobacterium bovis BCG. Scandanavian Journal of Immunology 26, 445-454.

Koshland, D. \& Botstein, D. (1980). Secretion of beta-lactamase requires the carboxy end of the protein. Cell 20, 749-760.

LAEMMLI, U. K. (1970). Cleavage of structural proteins during assembly of the head of bacteriophage T4. Nature, London 227, 680-685.

Matsudaira, P. (1987). Sequence from picomole quantities of proteins electroblotted onto polyvinylidene difluoride membranes. Journal of Biological Chemistry 262, 10035-10038.

Miura, K., Nagai, S., Kinomoto, M., Haga, S. \& Tokunaga, T. (1983). Comparative studies with various substrains of Mycobacterium bovis BCG on the production of an antigenic protein, MPB70. Infection and Immunity 39, 540-545.

Morris, J. A., Thorns, C. J. \& Woolley, J. (1985). The identification of antigenic determinants on Mycobacterium bovis using monoclonal antibodies. Journal of General Microbiology 131, 1825-1831.

Nagai, S., Matsumoto, J. \& Nagasuga, T. (1981). Specific skinreactive protein from culture filtrate of Mycobacterium bovis BCG. Infection and Immunity 31, 1152-1160.

Nagai, S., Miura, K., Tokunaga, T. \& Harboe, M. (1986). MPB70, a unique antigenic protein isolated from the culture filtrate of $B C G$ substrain Tokyo. Developments in Biological Standardization 58, $511-516$.

O'Callaghan, C. H., Morris, A., Kirby, S. M. \& Singler, A. H. (1972). Novel method for detection of beta-lactamases by using a chromogenic cephalosporin substrate. Antimicrobial Agents and Chemotherapy 1, 283-288.

Pugsley, A. (1989). Later stages in the prokaryotic secretory pathway. In Protein Targeting, pp. 112-125. Edited by A. Pugsley. London: Academic Press.

RADFORD, A. J., WoOD, P. R., Billman-Jacobe, H., Geyson, H. M., Mason, T. J. \& Tribick, G. (1990). Epitope mapping of the Mycobacterium bovis secretory protein MPB70 using overlapping peptide analysis. Journal of General Microbiology 136, 265-272.

Sambrook, J., Fritsch, E. F. \& Maniatis, T. (1989). Molecular Cloning: a Laboratory Manual. Cold Spring Harbor, NY; Cold Spring Harbor Laboratory.

SANGer, F., Nicklen, S. \& Coulson, A. R. (1977). DNA sequencing with chain terminating inhibitors. Proceedings of the National Academy of Sciences of the United States of America 74, 5463-5467.

Schoner, B. E., Hsiung, H. M., Belagaje, R. M., Mayne, N. G. \& SCHONER, R. G. (1984). Role of mRNA translational efficiency in bovine growth hormone expression in Escherichia coli. Proceedings of the National Academy of Sciences of the United States of America 81, 5403-5407.

SutclifFe, J. G. (1978). Nucleotide sequence of the ampicillin resistance gene of Escherichia coli plasmid pBR322. Proceedings of the National Academy of Sciences of the United States of America 75, 3737-3741.

Terasaka, K., Yamaguchi, R., Matsuo, K., Yamazuki, A., Nagai, S. \& YamadA, T. (1989). Complete nucleotide sequence of immunogenic protein MPB70 from Mycobacterium bovis BCG. FEMS Microbiology Letters 58, 273-276.

VON HEIJNE, G. (1988). Trancending the impenetrable: how proteins come to terms with membranes. Biochimica et Biophysica Acta 947, 307-333.

Vordermeier, H. M., Harris, D. P., Roman, E., Lathigra, R., Moreno, C. \& IVANYI, J. (1991). Identification of T cell stimulatory peptides from the $38-\mathrm{kDa}$ protein of Mycobacterium tuberculosis. Journal of Immunology 147, 1023-1029.

WALEY, S. G. (1981). An easy method for the determination of initial rates. Biochemical Journal 205, 631-633.

Whipple, D. L., Le Febure, R. B., Andrews, R. E., Jr \& Thiernann, A. B. (1987). Isolation and analysis of restriction endonuclease digestive patterns of chromosomal DNA from Mycobacterium 
paratuberculosis and other mycobacterium species. Journal of Clinical Microbiology 25, 1511-1515.

WoOd, P. R., Ripper, J., Radford, A. J., Bundesen, P. G., Rylatt, D. B., Cottis, L. E., John, M. \& Plackett, P. (1988). Production and characterization of monoclonal antibodies specific for $\mathrm{Myco}$ bacterium bovis. Journal of General Microbiology 134, 2599-2604.
Wood, P. R., Corner, L. A., Rothel, J. S., Ripper, J. L., Fifis, T., McCormick, B. S., Francis, B., Melville, L., Small, K., DE Witte, K., Tolson, J., Ryan, T. J., De Lisle, G. W., CoX, J. C. \& JONES, S. L. (1992). A field evaluation of serological and cellular diagnostic tests for bovine tuberculosis. Veterinary Microbiology 31, $71-79$. 